\title{
The creation of China's lenient punishments for those confessing to their crimes and accepting punishments in criminal cases and its theoretical reflection
}

\author{
Zehua Lyu \\ Ocean University of China, \\ 238, Songling Road, Laoshan District, Qingdao City, Shandong Province, 266100, \\ People's Republic of China
}

For citation: Zehua Lyu. 2021. "The creation of China's lenient punishments for those confessing to their crimes and accepting punishments in criminal cases and its theoretical reflection". Vestnik of Saint Petersburg University. Law 2: 401-418. https://doi.org/10.21638/spbu14.2021.210

\begin{abstract}
The reform to improve the system of admitting guilt and accepting punishment for leniency is one of the important measures to "promote the reform of the jury-centered litigation system", which is parallel to the substantial reform of court hearings. After pilot reform, it was finally confirmed by legislation. From the perspective of legislative norms, the leniency system of confession to a crime and acceptance of punishment includes basic principles, applicable standards for confession and acceptance of punishment, procedural norms and a system for the protection of rights. From the analysis of its nature, it is a diversion mechanism of criminal procedure, rather than a plea-bargaining system, which mainly implements the statutory penalty and is supplemented by the application of discretion and also embodies voluntary confession and other Chinese characteristics. The reform to the leniency system of admitting to a crime and accepting punishment contributed to the development of the conceptual and theoretical system of the leniency system and formed a series of theoretical systems for pleading guilty with Chinese characteristics: the generation of the penalty theory of postcrime behavior, a balance of justice and efficiency of the program from a simple theory, and the development of the effective defense system in China. It is particularly noteworthy that the system of admitting guilt and accepting punishment for leniency in China is a sentencing negotiation system rather than a conviction negotiation system.
\end{abstract}

Keywords: China, reform, guilt, punishment, leniency, voluntary, plea bargain.

\section{Introduction}

In order to realize the Chinese dream of the great rejuvenation of the Chinese nation, on October 23, 2014, the Fourth Plenary Session of the $18^{\text {th }}$ Central Committee of the Communist Party of $\mathrm{China}^{1}$ proposed the overall goal of comprehensively advancing the rule of law: building a socialist legal system with Chinese characteristics and building a socialist country ruled by law. In the field of criminal justice, a major deployment of "advancing the reform of the trial-centered litigation system" has been proposed. Court trials will develop towards substantive trial, and the overall rule of law in criminal procedure

1 "Communique of the Fifth Plenary Session of the $19^{\text {th }}$ CPC Central Committee, October 29, 2020". Xinhuanet. Accessed March 4, 2021. http://cpc.people.com.cn/n1/2020/1029/c64094-31911510.html. (In Chinese)

(c) St. Petersburg State University, 2021 
will be increasingly perfected. However, in order to conserve judicial resources, it is necessary to simultaneously promote the division of complicated and simple criminal cases. Therefore, the confession and punishment system must be improved and reformed concurrently. Previously, in June 2014, the ninth meeting of the Standing Committee of the Twelfth National People's Congress passed a decision authorizing the Supreme People's Court and the Supreme People's Procuratorate to conduct pilot work on fast-track sentencing procedures for criminal cases in 18 regions including Beijing city ${ }^{2}$. The fast-track sentencing procedure has been carried out as a precursor to reform of the confession and punishment system. In July 2016, the Twenty-Sixth Meeting of the Central Leading Group for Comprehensive and Deepening Reform reviewed and approved the Pilot Program of Imposing Lenient Punishments on Those Confessing to Their Crimes and Accepting Punishments in Criminal Cases ${ }^{3}$. In September 2016, the $22^{\text {nd }}$ session of the standing committee of the $12^{\text {th }}$ National People's Congress ${ }^{4}$ passed a decision authorizing the supreme people's court and the supreme people's procuratorate to pilot lenient punishments on those confessing to their crimes and accepting punishments in criminal cases in the aforementioned areas. The fast-track sentencing procedure pilot was formally incorporated into the reform to improve the system of pleading guilty and leniency punishment. In November of the same year, the Supreme People's Court, the Supreme People's Procuratorate, the Ministry of Public Security, the Ministry of National Security, and the Ministry of Justice jointly issued the Measures for carrying out pilot work on the system of leniency of punishment for pleading guilty in criminal cases in some regions ${ }^{5}$. The pilot work was officially launched.

As of July 2018, a total of 181177 criminal cases have been concluded under the confession and punishment system in 18 pilot district courts, accounting for 52,3\% of the trial courts' trials. The number of pilot cases from "none to many" and "less to many" has steadily increased, and relevant systems and mechanisms have been continuously improved. This has resulted in timely and effective punishment of crimes, the strengthening judicial protection of human rights, promoting fairness and justice, and optimizing the allocation of judicial resources. On October 26, 2018, the Decision to Amend the Criminal Procedure Law of the People's Republic of China was adopted at the $6^{\text {th }}$ Session of the Standing Committee of the Thirteenth National People's Congress (hereinafter referred to as the "Decision"), and it included the experience in pilot work, established the principle of confession and punishment being lenient in accordance with the law, and regulations

2 Decision of the Standing Committee of the National People's Congress on the Authorization of the Supreme People's Court and the Supreme People's Procuratorate to Carry Out the Pilot Program of Speedup Trial Procedure for Criminal Cases in Some Areas, enact June 27, 2014. Accessed March 4, 2021. http:// www.npc.gov.cn/npc/xinwen/2014-06/28/content_1869454.htm. (In Chinese)

3 " The $26^{\text {th }}$ meeting of the Central Leading Group for Comprehensively Deepening Reform was held on July 22, 2016". Xinhuanet. Accessed March 4, 2021. http://www.gov.cn/xinwen/2016-07/22/content_5093982.htm. (In Chinese)

4 "The $22^{\text {nd }}$ session of the standing committee of the $12^{\text {th }}$ National People's Congress was held on September 3, 2016". The Xinhua News Agency. Accessed March 4, 2021. http://www.npc.g ov.cn/zgrdw/npc/ cwhhy/12jcwh/node_30883.htm. (In Chinese)

${ }_{5}$ Measures for carrying out pilot work on the system of leniency of punishment for pleading guilty in criminal cases in some regions. Enacted November 11, 2016. Accessed March 4, 2021. https://xingbianjun. com/1196.html. (In Chinese) 
such as fast-track sentencing procedures and on-duty lawyers were added to consolidate the reform results in legal form ${ }^{6}$.

\section{Basic research}

\subsection{A normative analysis of the leniency system of the admission of guilt and the acceptance of punishment in China}

Based on the experience of the pilot reforms and taking into account the results of academic research, the 2018 Criminal Procedure Law ${ }^{7}$ regulates the system of leniency for confession to crime and acceptance of punishment. First of all, in the first chapter of the first part of the Criminal Procedure Law, the principle that a guilty plea and acceptance of punishment in criminal cases can be dealt with leniently in accordance with the law is clarified, the procedural provisions of pleading guilty and punishment in criminal cases is improved, and the protection of the rights of the parties is strengthened.

\subsubsection{The principle of "admitting guilt and acceptance of punishment in criminal cases can be dealt with leniently in accordance with the law" was established}

Criminal proceedings in Article 15 of the Law "criminal suspects and defendants voluntarily and truthfully confessed his crime, no objection to the alleged facts of the crime, willing to accept the punishment, may be treated leniently according to law". Pursuant to this, from the position of the basic principle, it establishes the legal application relationship where admission of guilt and acceptance of punishment can be dealt with leniently according to law.

"Admit guilt" means that the suspect or defendant voluntarily and truthfully confessed his crime and has no objection to the facts of the alleged crime. Acknowledging the main criminal facts of the accusation, and challenging only the individual factual circumstances, or expressing acceptance of the opinions of the judicial organs, although defending the nature of the act, does not affect the determination of a "guilty plea". If a criminal suspect or defendant commits several crimes and only truthfully confesses to one of the crimes or part of the facts, the "guilty plea" will not be determined for the whole case, and the leniency system of the admission of guilt, and the acceptance of punishment will not be applicable. But for the part that was truthfully confessed to, the people's procuratorate may propose a lenient punishment, and the people's court may impose a lenient punishment (The guidelines on the application of the system of leniency for guilty plea and punishment dated 11.10.2019. No. 6) ${ }^{8}$.

6 "The Supreme People's Court Application of the Pleniency System of admitting the crime and accepting the punishment in Criminal Prosecutions". 2018. Yishan Pedestrian. Accessed December 18, 2018. http://www.360doc.com/content/18/1218/07/39717550_802564805.shtml. (In Chinese)

7 The Criminal Procedure Law, enacted in 2018. Accessed April 19, 2021. http://www.npc.gov.cn/npc/ c12435/201811/59b0fd9941804636b9e403d17d6e3ebf.shtml. (In Chinese)

8 The guidelines on the application of the system of leniency for guilty plea and punishment dated 11.10.2019. Accessed October 24, 2019. https://www.spp.gov.cn/spp/xwfbh/wsfbh/201910/ t20191024_435829.shtml. (In Chinese). 
"Accept Punishments" means that the suspect or defendant sincerely repents and is willing to accept punishment. "Accepting Punishments" is manifested as a willingness to accept punishment during the investigation stage; acceptance of the prosecution or nonprosecution decision proposed by the People's Procuratorate during the review and prosecution stage, recognition of the sentencing proposal of the People's Procuratorate, and signing a recognizance to admit guilt and accept punishment. It also implies that at the stage of trial, the defendant confirms to sign the letter of affidavit voluntarily and is willing to accept the penalty (No. 7).

The leniency treatment includes both a lenient punishment and a simplification of the procedure (No. 8). In determining the extent of leniency, it is necessary to determine the limits and the magnitude of leniency through comprehensive consideration, by distinguishing the different stages of the proceedings, the value and significance of the investigation of the facts of the case, whether there are genuine expressions of remorse, and the seriousness of the crime. In penal evaluation, active confession is better than passive confession, early confession is better than late confession, thorough confession is better than incomplete confession, and stable confession is better than unstable confession (No. 9).

This principle basically establishes a contingent of logical correlations between "admission of guilt" "acceptance of punishment" and "leniency" treatment: those who confess their crimes or accept punishment may be given leniency according to law. Among them, the basic premise for the establishment of the logical relationship of "those who admit guilt and accept punishment can be lenient" is "voluntary", the logical paradigm is the probabilistic relationship of "can", and the treatment of leniency is "according to law". However, the application of "may" is not always applicable. Whether there will be leniency towards the criminal suspect or the defendant after admitting his guilt and accepting his punishments shall be decided by the judicial organ according to the specific circumstances of the case (No. 5). "May be granted leniency" means that it shall generally reflect the spirit of laws and policies and be treated leniently. However, there cannot always be leniency. If a suspect's or defendant's crime nature and its harmful consequences are especially serious, whose criminal means are particularly cruel, or whose social influence is particularly egregious, and whose guilty plea and punishment are not sufficient to be given a lighter punishment, the individual shall not be given a lenient punishment according to law (No. 8).

Although there is a logical or probable relationship between admitting guilt and accepting punishments and having leniency considered, the accused is provided with judicial rights by law as well as interests that can be lenient. This is a legal right that should be respected and protected. From the perspective of rights, admitting guilt and accepting punishments should be taken into consideration for leniency. From the perspective of the judicial application of the prosecution subject and the adjudicative subject, there are other uncertain situations that affect whether those admitting guilt and accepting punishments can be dealt with leniently, as well as severe and aggravated punishment. Therefore, those who admit guilt and accept punishments may be considered for leniency. Therefore, the legislation constructs a kind of logical applicable relationship with discretion from the perspective of prudence. 


\subsubsection{The procedural norms for admitting guilt and accepting punishment for leniency are improved}

A pre-trial procuratorial led leniency procedural system with criminal suspects, defenders (or duty lawyers), and victims participating has been established.

The investigation link provides basic procedures for the leniency of confession and punishment. First, it is stipulated that investigators should inform criminal suspects of their statutory obligations to provide a truthful confession of their crimes and understand the right to know in a timely manner. Secondly, the system of on-duty lawyers in detention centers has been implemented to ensure timely legal service assistance for criminal suspects. Thirdly, the on-duty lawyer or defense lawyer shall provide legal assistance to the criminal suspect who confesses to their Crimes and accepts punishments in a timely manner, such as legal advice, procedural selection suggestions, and application for changing to compulsory measures. Finally, the norms facilitate the meeting of the suspect with the on-duty lawyer or defense lawyer. The above-mentioned measures ensure that the admission of guilt and acceptance of punishment is made voluntarily with a full understanding of the nature and legal consequences of the confession.

The prosecution process provided a complete procedure for the leniency of confession and punishment. First of all, in addition to informing the suspect of litigations rights, the people's procuratorate should inform the criminal suspect of the legal provisions for admitting to the crime and accepting punishment, in order to ensure that his right of admitting and accepting punishment can be considered for leniency. Secondly, the procuratorate shall listen to the relevant opinions of the criminal suspect, defender or on-duty lawyer, the victim and his litigation agent on the process of admitting to the crime and accepting the punishment. Third, where the duty lawyer provides legal services for admitting the crime and accepting punishment, the People's Procuratorates should provide the duty lawyer with conveniences to understand the relevant situation of the case. Finally, on the premise of ensuring voluntariness, those who agree to the application of the sentencing suggestions and procedures put forward by the procuratorate shall sign a recognizance to admit guilt and accept punishment in the presence of the defender or the lawyer on duty.

During the trial, a fair judicial review and trial procedure is provided to ensure the implementation of the leniency to those who admit to their crimes and accept punishments. First of all, for the defendant who pleaded guilty, a presiding judge is added to inform those admitting to their crimes of the legal provisions of leniency in addition to notifying them of litigious rights to review the voluntariness, and to examine the authenticity and legality of admitting to the crime and accepting punishment. Secondly, there are three types of procedural designs, namely, fast-track sentencing procedure, summary procedure, and an ordinary procedure that can be selected for use by the defendant who admits to the crime and accepts punishment. Thirdly, the crime charged and the recommendation of sentencing by the people's procuratorate shall be generally adopted. The law increased the obligation of the court to review and correct the mechanism for those who admitting to their crimes and accepting punishments. Where a sentencing proposal is obviously inappropriate, or if an objection is raised, the procuratorate may adjust the sentencing proposal. If it is still apparently inappropriate after not adjusting or adjusting the sentencing proposal, the court shall make a judgment in accordance with the law. For those who are not guilty or should not be investigated for criminal responsibility, those 
who plead guilty involuntarily, or the charges prosecuted are inconsistent with the charges determined by the trial, they may not be bound by the charges and the recommendation on sentencing charged by the procuratorate and a judgment shall be made in accordance with the law. A program conversion mechanism was provided. If it is found that the case does not conform to the applicable circumstances of admitting to the crime and accepting punishment or that the case is not suitable to be applied to the trial of the provisional adjudication procedure, the case shall be converted into a fair procedure and retried.

\subsubsection{Enhancement of the protection of parties' rights in applying the procedure for admitting to the crime and accepting punishment}

According to China's 2018 criminal procedure law, there are new provisions for criminal suspects and defendants who confess their crimes and face punishment to protect their litigation rights.

First, the right to know of the right of admitting to the crime and accepting punishment was realized by stipulating that the People's Court, the People's Procuratorate, and the public security organs be informed of the "legal provisions for those who admit guilt and accept punishment". Through the provision of a duty lawyer system, the duty lawyers provide legal assistance to criminal suspects and defendants, advice on the selection of procedures, application for changes to compulsory measures, and advice on the handling of a case. The legal defense right of criminal suspects and defendants has been improved.

Secondly, the legislation stipulates that admitting to the crime and accepting punishment becomes an element of social risk judgment, which can affect the application of compulsory measures of arrest. "In the process of approving or deciding an arrest, the nature and circumstances of the suspected crime, the admission of guilt, and the acceptance of punishment, among others, for a criminal suspect or defendant shall be considered as factors of a possible danger to the society" (The Criminal Procedure Law of the People's Republic of China, No. 81-2) $)^{9}$. And in the prosecution individual rights have been improved.

Thirdly, by arranging the right to a timely meeting with the defender (or the lawyer on duty), the right to the presence of a defender (or the lawyer on duty) when the statement of confession and punishment is signed, and the right to the negotiation with the procuratorial organ and the victim's party to admit guilt and accept punishment and leniency, the voluntary guarantee of admitting to the crime and accepting punishment is fully realized.

Fourthly, if the criminal suspect voluntarily and truthfully confesses to the facts of the suspected crime, if there is a major contribution or the case involves significant national interests, the public security organ may withdraw the case with the approval of the Supreme People's Procuratorate, and the People's Procuratorate may make a decision not to prosecute, or one or more of the crimes are not prosecuted (No. 182). By not pursuing prosecution, the guilty suspect is provided with the treatment of pre-trial termination of litigation, which realizes the principle of penalty forgiveness.

Finally, the voluntary judicial review and guarantee of a guilty plea and acceptance of punishment are realized through substantive examination of the voluntary guilty plea and acceptance of punishment, the authenticity and legality of the statement of a guilty plea

9 The Criminal Procedure Law of the People's Republic of China 26.10.2020. Accessed November 5, 2018. http://www.npc.gov.cn/npc/c12435/201811/59b0fd9941804636b9e403d17d6e3ebf.shtml. (In Chinese) 
and acceptance of punishment, the addition of the applicable quick decision procedure, the conversion of the trial procedure after the occurrence of revocation, and protection of the right to appeal.

\subsection{A study on the special nature of the leniency system of admitting the crime and accepting the punishment in China}

Based on the analysis of the 2018 Chinese Criminal Procedure Law's normative text, it is not difficult to find that the leniency system of admitting to a crime and accepting punishment not only has some characteristics of Anglo-American plea bargaining (Maynard 1984) and continental negotiation justice, but it also has distinctive Chinese characteristics.

\subsubsection{Procedural shunting mechanism to save judicial resources}

From the analysis of the normative text of the new Criminal Procedure Law, the simplification of the application of the leniency system of admitting to a crime and accepting punishment is only a division mechanism and it is an important instrument to optimize the allocation of judicial resources. Through the voluntary confession of the accused, the cost of investigating the case is actually reduced, and the cost burden of the trial procedure is reduced through the application of the summary procedure and quick-decision procedure. This makes the instance of a guilty plea and non-guilty plea split in the application of procedure and ensures the reasonable allocation of national judicial resources. At the same time, the application of the leniency system reduces unnecessary procedural burdens, reduces the possibility of applying detaining coercive measures, reduces or eliminates tedious interrogation and trial litigation, and it reduces judicial litigation for the prosecution, the victims, the defense lawyers, and other litigants.

\subsubsection{Legal doctrine is given priority, discretion is applied as a supplement}

Based on the analysis of the norms of the criminal procedure law of 2018, in the process of reviewing and prosecuting, there is no expression in the legal norms for the procuratorial organ to put forward the sentencing proposal and the defense party to accept the recommendation. Among them, the sentencing recommendation of the prosecution authority is rigid, and the defense only has the right to accept or select. Although there are more opportunities for criminal suspects and victims to participate in the agreement between confession, punishment, and leniency, this will not be the judicial application of the consultative criminal justice or plea-bargaining system that breaks through the principle of proportionality between crime and punishment. The sentencing recommendation of the prosecution authority is the application of the sentencing discretion based on the criminal law and the recommendation on the standardization of sentencing, which is based on the corresponding penalty range for confession and recognition of punishment. It reflects the strong statutory sentencing. Therefore, the application between confession and punishment and leniency should be activity carried out in accordance with the law. Even if there is a negotiation activity, it is also a relationship of communication and choice conducted in accordance with the law. It is necessary to clearly see that legalism is domi- 
nant, and the application of discretion is only discretion within the legal framework, and discretion should be rigidly restricted and constrained by legalism.

\subsubsection{Reconciliation of the accused party, the victim, and the prosecution party has been realized}

From the analysis of the 2018 Criminal Procedure Law, the leniency system of admitting to a crime and accepting punishment was finally established, and two "reconciliations" were achieved. First, the reconciliation between the procuratorate, the representative of the organs of state power, and the prosecuted party on leniency in sentencing is embodied in the determination of sentencing recommendations. The second is reconciliation between the accused and the victim, which shows that the criminal suspect takes the initiative to compensate for the loss, make amends and obtain the victim's understanding, etc. This is the first reconciliation between the public authority and the accused in China. On the basis of the procedure for the reconciliation of public prosecution cases established in the criminal procedure law in 2012, the reconciliation between the state prosecution authority and the accused has been implemented. Of course, this kind of reconciliation should be carried out in accordance with the law, in the sentencing of leniency reconciliation, and with a strict nature of the law and legal restrictions.

\subsubsection{It is only leniency negotiation in sentencing, not a trade between crime and punishment}

On the basis of complying with statutory doctrine, the agreement reached between the two parties in the leniency system for admitting to a crime and accepting punishment is a question of sentencing, which is different from the penalty transaction in Britain and the United States (Maynard 1984), not the crime transaction. The sentencing suggestions made by the public prosecutor's office should be implemented strictly in accordance with the statutory requirements of the leniency system and should not be applied in violation of legal norms. Whether to admit to guilt and accept the punishment or not reflects the initiative and willingness of the accused, and moreover it reflects the trust and acceptance of the penalty preference provided by the national law. It should be noted that there is no reduction of the charges, and the sentencing discretion is applied to induce the meaning of confession. Among them, there is nothing to reduce the charges and the application of sentencing discretion to induce confessing to the crime and accepting punishment.

\subsubsection{Pursuit of substantial truth should not be based on the confession obtained by prosecution activities}

From the analysis of the law, the investigation and prosecution organs that determine the truth still need to collect evidence comprehensively and objectively in the investigative process and prosecution, and there should not be any reduction of the litigation function due to the appearance of a confession to the crime and acceptance of punishment. As for the judicial organs, it is still necessary to conduct a substantive examination of the voluntary nature of admitting to the crime and accepting punishment, the legality and authenticity of the statement of confession. In spite of the simplified application of the summary 
procedure and the fast-track sentencing procedure, the court should earnestly perform its judicial duties in the examination of the case of a guilty plea and punishment and leniency, and conduct a comprehensive and substantive examination from the aspects of the admissibility of evidence, fact finding, conviction and sentencing, procedural operation, participation of all parties and reasoning of suggestions. If the sentencing proposal is found to be in obvious violation of the principle of proportionality of criminal responsibility and punishment, in violation of the same judgment in similar cases and the uniform application of the law, in violation of judicial justice or the people's concept of fairness and justice, in violation of the general judicial understanding and other obvious improper circumstances, the people's procuratorate shall be informed to adjust the sentencing proposal and provide an explanation. If the procuratorial organ does not adjust or adjust the recommendation on sentencing, and the court still feels that the sentencing is inappropriate, it shall implement the principle of "the court's unified right to conviction", conduct a fair trial to convict and assess the sentence on the defendant (Hu 2019).

\subsubsection{Ensuring "voluntariness" is the basis for applying the leniency system}

"The defendant's confession should be the defendant's voluntary admission that the alleged act constituted a crime, but it does not include the accused's knowledge of the nature of his act" (crime, crime pattern, etc.) (Chen, Kang 2016, 4). The design of the leniency system is more focused on the accused's true "voluntary", sincere repentance, substantial repentance behavior performance. Therefore, "voluntariness" is not a kind of strategic judicial transaction under the premise of mastering the case and evidence controlled by the investigation and prosecution organs. As a result of the system, there is no need for more defense lawyers to inquire about the progress of the investigation in a timely manner, so as to carry out various kinds of litigation activities. The accused does not need to increase his right to know further as well as the right to participate in the process, the right to defense, or even the right to investigate and obtain evidence. He must only consider whether to accept "admitting to the crime and accepting punishment with leniency" granted by law. Accepting the legal right to plead guilty and accept punishment for leniency implies that the accused truthfully confess to the crime and if not, then he is subjected to the substantive trial procedures.

\subsection{China's reform of leniency in regard to confession and punishment has given rise to outstanding legal principles}

The consummation and reform of the system of admitting guilt and accepting punishment for leniency is not only enhancing knowledge on the practical pilot experience, but it is also assisting with the systemic generation of legal norms, and more importantly, the formation of a new theory system.

\subsubsection{The theoretical system of the concept of leniency for confession and punishment is generated}

Because of its applicable scope, essential ability to expand and draw lessons from different related systems, the improvement and reform of the system of admitting to a crime 
and accepting punishment in China is bound to form a comprehensive role, with Chinese characteristics, and reflect the judicial practice and the system outside of reasonable reference in regard to the new connotation of the system- to form a new theoretical system.

First, the scope of application is expanded. In the new period, the concept of the leniency system proposed by China's judicial reform has expanded from the system of "voluntary surrender" and "meritorious service" in the substantive law and the new system of "confession can be lenient" to a complex and simple criminal procedure diverging mechanism. For example, in the "pilot plan" adopted at the $26^{\text {th }}$ meeting of the central leading group for comprehensively deepening reform on July 23, 2016, it was pointed out that the system of admitting guilt and accepting punishment for leniency in criminal proceedings should be improved... a clear withdrawal and non-prosecution procedures, to standardize the pre-trial and trial procedures. In this regard, the research understanding of the academic community is also deepening. For example, some scholars believe that "from the perspective of criminal integration, the leniency system of admitting to a crime and accepting punishment... can correctly grasp the position of this system in China's criminal rule of law system" (Xiong 2016, 105). Therefore, some scholars believe that the leniency system should refer to the comprehensive legal system composed of a series of specific legal systems and litigation procedures that encourages, guides and guarantees the criminal suspects and defendants who are really guilty to voluntarily confess to their crimes and accept punishments, and grant them leniency in criminal proceedings $(\mathrm{Gu}$ $2016,131)$. In terms of the content of the specific system, the discussion within the academic circle has gradually shifted from the entity of admitting to the crime and accepting punishment to the trial procedure and even the simplicity of pre-trial procedure and the leniency of litigation processing, and even expanded the view that it is a kind of evidence system (Wang 2017, 20).

Secondly, the extension of the essence of connotation. According to official viewpoints, the leniency system is carried out from the perspective of facilitating the truthful confession of criminal facts, cooperating with judicial organs in handling cases in accordance with the law, and saving judicial resources (Li 2016). For example, the "Opinions on Comprehensively Deepening the Reform of the People's Court" issued by the Supreme People's Court in February 2015 required: "We should clarify the procedures, punishment standards and handling methods of defendants' voluntary confession, voluntary acceptance of punishment, and active withdrawal of stolen assets and compensation, establish a mechanism to separate guilty and non-guilty cases, and optimize the allocation of judicial resources". In this regard, the mainstream academic view is basically the same: the admission of guilt and the acceptance of punishment in criminal proceedings embodies the efficiency concept based on justice, bearing the spirit of modern judicial tolerance, helping to explore the formation of a non-confrontational litigation pattern, and further realizing the optimal allocation of judicial resources (Chen 2016, 51-53). Based on such an understanding, the leniency system of admitting guilt and accepting punishment is embodied in the criminal responsibility theory of the defendant's behavior after the crime, that is, the penitent behavior of admitting guilt and accepting punishment carries the connotation of having a reduced penalty. From the procedural point of view, the procedure has been simplified, and even the litigation closure (withdrawal, not prosecution) and other aspects in order to save judicial resources. With the deepening of research, the academic community also constantly finds that the meaning of the lenient procedure for a guilty plea is not only to 
simplify the procedure to save judicial resources, but also to reflect the implication that admitting guilt and accepting punishment can be procedurally relaxed. For example, in the application of compulsory measures, there is a judgment basis for the reduction of personal danger due a confession to the crime and acceptance of punishment, so the lighter compulsory measures can be applied. From the perspective of evidence, the confession of admitting to a crime belongs to a type of evidence, which reflects the more convenient judicial proof and the different values at different stages of the litigation process (Wang $2017,20)$. Of course, from the perspective of protecting the accused's human rights, and from the notion of litigation behavior, we can also explore some new connotations of the leniency system: for example, "there is no defense lawyer to provide effective assistance to the person being prosecuted. There cannot be a fair leniency system of admitting to a crime and accepting punishment" (Wang 2017, 27-28). Different from the "private cooperation model in criminal litigation" of criminal reconciliation (Chen 2006, 15), the confession negotiation procedure is a "public cooperation model in criminal proceedings" reached by the national public prosecution agency and the defendant through negotiation (Hu 2017, 170).

Finally, institutional derivatives are diverse. The academic community has also formed different views on the interrelationship between the leniency system of admitting to a crime and accepting punishment and China's existing system and the various pleabargaining systems in other countries. For example, some people think that "The system of the admission of guilt and the acceptance of punishment is an extension of the system established on the basis of criminal suspects and defendants charged by the investigative organs and the procuratorial organs. It is applicable to any case, type of procedure, and widely exists in the criminal process. It is not a litigation system that exists independently of the norms of criminal substantive law and procedural law" (Chen 2016, 48). The above argument that the system of admitting guilt and accepting punishment for leniency is a comprehensive view of the connotation of entity and procedure is clear proof. This kind of viewpoint is the theory of system combination cognition, which advocates that the system of admitting guilt and accepting punishment for leniency belongs to the combination of China's inherent systems and procedures, rather than a new independent system. However, some people believe that the nature of the leniency system is a "public cooperation model in criminal proceedings" ( $\mathrm{Hu} 2017,170)$. In combination with the new measures such as withdrawing a case and the decision not to prosecute as stipulated in the pilot measures for leniency in confession, the leniency system of admission to guilt and acceptance of punishment belongs to the existing system combination, but it also has the content of system renewal and improvement, which exactly conforms to the reform slogan of system "perfection". However, some scholars believe that the leniency system does involve the promise of leniency made by the functional departments and the process of similar "negotiation" as well as whether the person being prosecuted should recognize such promise (Wang 2017, 27). From the perspective of innovation of criminal procedure, constructing a Chinese-style confession negotiation process is the core issue for improving the confession and punishment leniency system ( $\mathrm{Hu} 2017,170)$. This kind of view is a rational understanding formed from the comparison between the leniency system of admitting to a crime and accepting punishment and plea bargaining outside China, and the "criminal negotiation" system formed in the derivative development of various countries. Based on this point of view, the leniency system will have the same content as the system of criminal negotiation, which has a new connotation in the "lenient system of 
admitting to a crime and accepting punishment with Chinese characteristics" advocated by the academic circle.

\subsubsection{Post-sin confession of crimes as a result of punishment theory}

The traditional principle of adaptation between crime and punishment emphasizes the proportionality between criminal behavior and punishment, which is a concept of punishment for retribution. However, the behavior of admitting guilt and accepting punishment after a crime can be dealt with leniently in regard to the penalty, which breaks through the basic connotation of the old principle of crime and punishment, and blends with the merger punishment principle of modern retribution theory and preventive theory. According to the theory of merger punishment, the justification of punishment is based on the legitimacy of retribution and the rationality of crime prevention. Punishment based on retribution is the responsibility penalty, and the punishment based on the purpose of crime prevention is preventive punishment (Wang 2016, 112-113). Therefore, admitting to a crime and accepting punishment after a crime, as a general preventive element, has the ability to reduce the criminal responsibility of a crime. This theory not only has the policy support of China's criminal policy of "honesty and leniency" and "tempering justice with mercy", but also has the support of the concept of restorative justice, which provides a new theory for the perpetrator's infringement responsibility beyond the traditional penalty system. In addition, humanitarian-related criminal policies also have a guiding role in sentencing, including whether a certain factor has an impact on sentencing (Wang 2016, 112-113). Based on this, some scholars have suggested that in criminal law, the leniency to admitting the crime and accepting punishment can be considered as a principle in order to reflect the generally effective positive evaluation of those who admit to crimes accept the punishment... (Xiong 2016, 110). Therefore, based on the theoretical support of the policy basis, the theory of preventive punishment, restorative justice, and humane care, the behavior of the admission of guilt and the acceptance of punishment after a crime has the effect of generating a penalty discount, which leads to the formation and perfection of the theory of punishment for post-crime behavior. This leads to the formation and improvement of penalty theory. Regardless of whether "the admission of guilt" and "the acceptance of punishment" and specific "leniency" punishment are legal or discretionary, a relatively stable proportional relationship will be formed, and a new proportional relationship between the principle of adapting crime and punishment will be established. However, based on whether the "admission of guilt" and the "acceptance of punishment" behaviors have real penitence performance that reflect the degree of personal danger, the realistic possibility of rehabilitation of criminals, etc., and thus complying with the view of punishment for the purpose of crime prevention, specific systems need to be improved and standardized. Realizing the "penalty theory of post-crime behavior" can be truly implemented.

\subsubsection{The justice and efficiency theory of the leniency system of admission of guilt and acceptance of punishment in simple procedure is generated}

"Several Opinions on the Application of Ordinary Procedure for the Trial of "The Defendant's Pleaded Case' (Trial)" and "Several Opinions on the Application of the Sum- 
mary Procedure for the Trial of Public Prosecution Cases" will both improve the quality and efficiency of the trial of criminal cases, as the purpose of this opinion release... The simplifying of procedures, closing cases quickly, saving judicial resources, and promptly resolving social contradictions, should be the main value pursuit of procedural law of these documents (Wang 2016, 113). Both the quality of case handling and the efficiency of litigation are the basic connotations of procedural justice. In order to realize the procedural justice of the leniency system, the academic circle has also carried out sufficient theoretical argumentation: for example, the defendant's confession is used as the main basis for streamlining procedures, and its legitimacy is derived from the defendant's voluntary waiver of obtaining the right to a formal trial (Xiong 2016, 104). There are also opinions that this is the manifestation of the "Pareto two to eight theorem rule" of simple majority and complex minority in criminal proceedings (Li 2013). It is also believed that this is based on international consensus and the need for the protection of defendants' rights, such as the resolution of the 15th International Criminal Law Conference: "Simplified procedures shall not be applied to serious crimes and discretion in dealing with the defendant's right shall not be restricted by law. For other crimes, legislators should determine the requirements of the procedure and voluntary safeguards to ensure cooperation between the accused and the judiciary, such as the effective assistance of a defender to the accused. It is recommended that such proceedings be instituted in minor cases, to speed up the progress of criminal proceedings and better protect the rights of defendants" 10 . There are even opinions that correspond to the principle of adapting crimes and penalties in criminal law. The criminal procedure law should adhere to the principle of proportion to determine the degree of mitigation of litigation measures and the degree of simplification of litigation procedures. A guilty plea is an important factor to be considered (Xiong $2016,110)$. Based on the defendant's confession to the crime and acceptance of punishment, a consultative litigation model corresponding to the adversarial litigation model has been constructed. Negotiated justice includes both parties' negotiation-criminal reconciliation and negotiation-plea between the prosecution and the defense. The admission of guilt and acceptance of punishment of the accused is a precondition of the negotiation judicature (Xiong 2016, 110). With such a wealth of academic ideas, the leniency system is designed in the sense of litigation procedure, which results in some basic requirements for ensuring the fairness of the procedure: ensuring the voluntary choice of admitting to the crime and accepting punishment, full and comprehensive protection of the right to defense, procedural simplicity under the premise of ensuring the quality of the case, the procedural power restriction on admitting to the crime and accepting punishment, and the litigation framework for the protection of the rights of the person being pursued, etc. These specific system studies are all aimed at achieving the goal of procedural justice on the leniency system for admitting to a crime and accepting punishment.

\subsubsection{A new confession and punishment generated from a lenient criminal certificate}

Confession and punishment are not only a simple acknowledgement of "crime" and "penalty" in criminal substantive law, but also a true statement of the facts of the crime.

10 "Resolution of the International Criminal Law Conference". 2011. Association Internationale de Droit Pénal: 123. Beijing, Zhōngguó făzhì chūbăn shè Publ. (In Chinese) 
Therefore, in the sense of the prosecution's statement on the facts of the case, it is a type of evidence - the confession of the suspect and the defendant. The leniency system for confession to a crime and accepting punishment can obtain different evidence values in the collection of evidence during the investigation stage, the review of the evidence for examination and prosecution, and the conviction and sentencing in the trial. This not only saves judicial costs, but also reduces the burden of judicial certification (Wang 2017, 21-22). Because the confession of the criminal suspect and the defendant is direct evidence, it occupies an important position in the evidence system. The evidence status and value of confession evidence cannot be denied because of the need to eliminate and control the illegal evidence collection of torture. The evidence of "confessions of criminal suspects and defendants" implemented through the leniency system of confession and punishment can fully achieve its due judicial proof value. From the perspective of the standard of proof, the simplicity of the application in the procedure for admitting to a crime and accepting punishment has produced many new theoretical views. The 2016 central political science and law work conference proposed to "study and explore different types of cases, such as whether or not the defendant pleads guilty or not, the severity of the crime and the difficulty of the case, to implement differentiated standards of proof" (Li 2016). In this regard, there are certification requirements for "clear facts and sufficient evidence" to be adjusted through "critical evidence", "evidence guidance", etc (Zhang 2015, 45-46). It has been suggested that the degree of "beyond reasonable doubt" is needed to ensure the voluntary proof of the defendant's confession, but the proof of criminal facts and sentencing facts should be reduced to "approximate evidence" (Gao 2017, 111). Others believe that there are the theory of proof standards - "basic criminal facts" imply that the crime committed by the defendant is lower than the "beyond reasonable doubt" psychological proof requirements (Xie 2015, 143). According to this, three kinds of theories of proof standards can be formed: (Sun 2016, 14-15) "Theory of limited objects of proof" arising from the department of judicial practice denotes "basic facts" clear and "basic evidence" true and sufficient (Chen, Kang 2016, 8-9). Also, the "Reduction of burden of proof", which reduces the burden of proof on the prosecution as a result of the defendant's statement (Chen 2016, 55). The "simplification of evidence investigation" results from the simplified rules of trial procedures (Wei 2016, 91). It is not difficult to find that the differences of opinions are mainly focused on the cognition of the standard of proof: whether it is a subjective proof or an objective proof requirement, whether it includes the proof object or even a uniform requirement on the proof procedure. First of all, the definition of the essential connotation of the proof standard should be a question of the degree of pure cognition and judgment on "truth", "false", and "degree of doubt", which belongs to the epistemological category. This kind of requirement, whether it is a subjective requirement or objective standard, reflects the criterion for judging the true degree. Secondly, should the object of proof become the connotation of the proof standard? The difference in the number of proof objects reflects the comprehensiveness of knowledge. Of course, the more comprehensive and meticulous it is, the better it is to reveal the full picture of the facts, but it does not mean that the identification of "basic facts" and "key facts" cannot accurately determine the true recognition. Therefore, the requirements for the object of certification in the leniency procedure for confession to a crime and accepting punishment can be based on the complexity of the case and the severity of the case. In fact, the existence of confession evidence from criminal suspects and defendants has alleviated the 
pressure of proof to a certain extent, and it can expand the scope of the object of proof to achieve the expansion from "basic facts" and "key facts" to "comprehensive facts". Third, whether the frugality of the court investigation process affects the standard of proof. It is undeniable that the court investigation process is a method of proof and an effective way to achieve cognitive accuracy. However, in terms of the form and stage of judicial certification, evidence collection in the investigation process and the examination in the prosecution process have fulfilled the basic fact proof requirements. Especially in China, where the standard of proof for investigation, prosecution and trial is the same, the frugality of trial investigation procedure is not a device to lower the standard of proof. Moreover, testifying in a trial is more of a verification activity in which the judge investigates and the prosecution and the defense confront each other. This strict direct verbal principle and centralized trial mode is only a form of trial proof. There are also various forms of written review, listening, and out-of-court investigations. If the confession to a crime and acceptance of punishment procedure had a more adequate and effective defense, this may be more reliable than the pure trial form.

\subsubsection{Promote effective defense theory in China}

"As a legal system, the effective defense and invalid defense systems are deeply imprinted with American law, but as a legal theory, the effective defense theory and invalid defense concept have a universal value and represent the development direction of the criminal defense system" (Chen 2014, 104-105). It is undeniable that considerable progress has been made in the defense system of criminal litigation, which is typically reflected in the investigation: the development course of criminal suspect's right to defense has developed from no right to legal help, to lawyers providing "legal help" and then to a "lawyer's advocate" providing defense services. The reform of the leniency system needs to ensure that criminal suspects and defendants voluntary, authentically, and "intelligently", "knowingly", required by the American plea-bargaining system on admitting to a crime and accepting punishment ${ }^{11}$, must want to have a more adequate and effective defense system to ensure it (Wang 2017, 28). Some viewpoints even bluntly advocated that the perfect reform on the leniency system should ensure voluntariness, wiseness and being aware of the specific requirements of admitting to a crime and accepting punishment (Bian 2012, 19-21). There is no doubt that admitting to a crime and accepting punishment in the pre-trial will conducted under a strong prosecution of the investigation organ and the procuratorate, and it will be obtained under the circumstances of asymmetric evidence information. How can we ensure that the accused confesses and accepts punishment out of free will, and the choice is being made in a rational state, there is sufficient and comprehensive help from a lawyer in order to form the equality of litigation activities, the sufficiency of information acquisition, the rationality of litigation choice? By "establishing the concept of effective defense and establishing a quality control system aimed at regulating lawyers' defense is the only way for China's future development of criminal defense systems" (Chen 2014, 105). Learning from the experience of the effective defense system in the United States (Qi 2015, 127-130), the effective defense system in China needs to be developed from the following aspects: first, effective defense requires the adequacy

11 Brady v. U.S., 397 U.S. 742. 1970. Accessed March 4, 2021. https://supreme.justia.com/cases/ federal/us/397/818. 
and eligibility of services provided by a lawyer. The "Opinions on Carrying out Legal Aid Duty Lawyer Work" issued by the Supreme Court, the supreme people's procuratorate, the ministry of public security, the ministry of justice, and the legislative affairs commission of the National People's Congress and the "Measures on Carrying out Full-scale Pilot Work of Lawyer Defense for Criminal Cases" jointly issued by the Supreme People's Court and the Ministry of Justice called for the full coverage of the legal aid duty lawyer service and the full coverage of the lawyer's defense in criminal cases. This represents significant progress in effective defense, but more concrete measures are needed in terms of the quality of service and competence of lawyers. Secondly, the quality control index system of effective defense should be established to realize the reference basis of an effective defense standard. Thirdly, perfect the invalid defense review system and obtaint effective defense through reverse regulation. Finally, the relief system for invalid defense should be determined to provides the possibility for the defendant to correct the adverse litigation result caused by an invalid defense.

\subsubsection{The theory of the protection of the right to plead guilty and accept punishment with leniency came into being}

Respecting and protecting human rights is one of the goals of criminal procedure and it was written into the task norms of China's criminal procedure law in 2012. Through the two rounds of amendments to the Criminal Procedure Law, great progress in protecting the accused's human rights has been made in China: the principle against forced selfincrimination is enshrined in law, and the exclusion rule of illegal evidence is established, legal aid is transferred to the investigation link, and the investigation link has the right of lawyers to defend, etc. Reform of the system of leniency for the admission of guilt and acceptance of punishment will further boost the development of protecting human rights. From the perspective of comparative research, some scholars have argued that the simplification of trial procedures is a phenomenon that occurs after the rule of law has developed to a higher stage. For example, more than $90 \%$ of the application rate of the simplified procedures in the United States is supported by a list of important rights enjoyed by suspects before trial. However, our country's support in this regard is still quite weak. Therefore, the reform of the leniency system is not only a matter of simplification of the trial process in China. At the same time, it is more important to strengthen the protection of the rights of a series of pre-trial procedures. The latter is the solid foundation of the former's legitimacy. Judging by the difficulty of reform, the latter is bound to be an even harder task (Sun 2016, 19). For this reason, by referring to relevant systems outside the region, China can completely achieve the high standards of human rights protection from the improvement and reform of the system of leniency of confession to a crime and acceptance of punishment, so as to prevent innocent people from being forced or enticed to confess to their crimes, which will also promote the reform of the trial - centered litigation system. From the perspective of ensuring the voluntariness, wiseness, and consciousness of confession to a crime and acceptance of punishment, it is not enough to provide legal aid in form. It is also necessary to guarantee the accused in the pre-trial stage of investigation and prosecution, the right to know the information of criminal charges, the right to participate in the procedure, and the legal right to safeguard the application of various compulsory investigation measures. These levels of the rule of law should be 
substantially enhanced (Sun 2016, 19). In addition, there should even be the right of revocation and the right of relief with adverse procedural consequences for the confession of a crime and the acceptance of punishment in order to form the post-effect restriction on the right of strong prosecution. For the victims and other participants in the lawsuit, they will also obtain some new rights and guarantees from the leniency system. For example, when confessing and negotiating the penalty, the victim shall have the right to express his opinion, the right of recourse for compensation and timely compensation realized, the right to invite agents ad litem to participate in the negotiation of a guilty plea and penalty during investigation, etc. Therefore, the reform of the leniency system will bring about progress and enrichment of human rights protection, which will be more conducive to the reform of the litigation system centered on trials and the realization of complementary reforms that complement each other.

\section{Conclusions}

The reform of China's lenient system of admission of guilt and punishment is a supporting measure to carry out the reform of the litigation system centered on a trial. It achieves the goal of separating complicated and simple litigation in parallel with the substantive trial. Through the practice of the pilot reform and the standardized implementation, especially with the help of academic research, a relatively complete lenient system of admission of guilt and punishment has been formed. It includes both entity leniency and procedural simplification. It is reflected not only in the basic principles of criminal procedure, but also in the special procedures ${ }^{12}$. It should be noted that China's lenient system is not a plea-bargain system as in the US. It is merely a negotiation of penalties, not a bargain of criminal charges. The negotiation of penalty is strictly limited by law and the space of penalty discretion is limited. It attaches great importance to Chinese characteristics such as the voluntary protection of the confession based on "penitence". At the same time, the reform of the lenient system has also contributed to the renewal of some theories, such as penalty theory of post-crime behavior, justice and efficiency balance of the program from the simple theory, etc. With further judicial practice, China's lenient system of admission of guilt and punishment will encounter a series of problems and promulgate in-depth reform of the system.

\section{References}

Bian, Jianlin. 2012. "How to treat the defendant's guilty plea - a revelation of plea bargaining". Zhèngfă lùntán (zhōngguó zhèngfă dàxué) 20 (6): 19-23. (In Chinese)

Chen, Guangzhong, Ma Kang. 2016. "Several Important Issues of The leniency system of the admission of the crime and the acceptance of the punishment". Fălü kēxué 8: 3-11. (In Chinese)

Chen, Ruihua. 2006. "Private Cooperation Model in Criminal Proceedings". Făxué yánjiū 5: 15-52. (In Chinese)

Chen, Ruihua. 2014. "Effective Defense in Criminal Proceedings". Sūzhōu dàxué xuébào (zhéxué shèhuì kēxué băn) 5: 94-105. (In Chinese)

Chen, Weidong. 2016. "Research on $t$ the leniency system of the admission of the crime and the acceptance of the punishment”. Zhōngguó făxué 2: 48-64. (In Chinese)

12 Such as fast-track sentencing procedures, admission of guilt, cancellation of the case and nonprosecution for some special adimission of guilt, etc. 
Gao, Tong. 2017. "Research on the Proof Standards of Criminal Expedited Procedures". Făxué lùntán 2: 104-111. (In Chinese)

$\mathrm{Gu}$, Yongzhong. 2016. "Several Theoretical Issues on improving the leniency system of the admission of the crime and the acceptance of the punishment". Dāngdài făxué 6: 129-137. (In Chinese)

Hu, Ming. 2017. "Negotiating procedures for confession: patterns, problems, and bottom lines". Făxué 1: 169-177. (In Chinese)

$\mathrm{Hu}$, Yunteng. 2019. "The leniency system of the admission of the crime and the acceptance of the punishment is not a copy of western 'plea bargaining' or a Chinese version (depth Good text)". Accessed December 7, 2019. https://mp.weixin.qq.com/s/uE-MXjFphQLsOtXgx_iEsg. (In Chinese)

Li, Bensen. 2013. "The two-to-eight theorem in law -Quantitative Analysis Based on the Trial of Defendant's Plead Case”. Zhōngguó shèhuì kēxué 3: 85-105. (In Chinese)

Li, Yang. 2016. "Look at the weathervane of judicial reform in the year of crisis - the central focus political and legal work conference”. Rénmín făyuàn bào, $2^{\text {nd }} \mathrm{ed}$. Beijing, Ren Min Fa Yuan Xin Wen Chuan Mei Zong She Publ. (In Chinese)

Maynard, Douglas W. 1984. Inside Plea Bargaining-The language of negotiation. New York, London, Plenum Press.

Qi, Jianjian. 2015. "Effective Right of Defense in Plea Bargaining in the United States". Bǐjiào făxué 6: 126142. (In Chinese)

Sun,Yuan. 2016. "The Proof Standards for Cases of the admission of crime and the acceptance of the punishment”. Guójiā făguān xuéyuàn xuébào 11: 14-19. (In Chinese)

Wang, Minyuan. 2017. "Research on difficult problems of the leniency system of the admission of the crime and the acceptance of the punishment". Zhōngguó făxué 1: 17-34. (In Chinese)

Wang, Ruijun. 2016. "Interpretation of 'the admission of the crime and the acceptance of the punishment' from the perspective of substantive law and research on its judicial application". Zhèngzhì yŭ fălù 5: 108-117. (In Chinese)

Wei, Xiaona. 2016. "Improving the system of admitting guilty and accepting punishment for leniency: Keyword development in Chinese context”. Făxué yánjiū 4: 79-98. (In Chinese)

Xie, Dengke. 2015. "The standard of proof in criminal summary procedure”. Dāngdài făxué 3: 135-143. (In Chinese)

Xiong, Qiuhong. 2016. "A theoretical review and system improvement of the leniency system of the admission of the crime and the acceptance of the punishment". Făxué 10: 97-110. (In Chinese)

Zhang, Jiansheng. 2015. "Exploration and theoretical construction of pilot procedure for Fast-Track Sentencing Procedure”. Rénmín jiǎnchá 9: 41-48. (In Chinese)

Author's information:

Zehua Lyu — PhD in Law; benlae@163.com 